\title{
FGF3 Gene Amplification
}

National Cancer Institute

\section{Source}

National Cancer Institute. FGF3 Gene Amplification. NCI Thesaurus. Code C147064.

A molecular genetic abnormality indicating the presence of multiple copies of the FGF3 gene. 